\title{
Dental trauma and oral health-related quality of life in schoolchildren from public schools of a southern Brazilian city
}

\author{
Trauma dental e o impacto na qualidade de vida de escolares da rede pública em uma cidade no sul do \\ Brasil
}

\author{
Abelardo Nunes LUNARDELLI ${ }^{1}$ \\ (iD) ORCID iD 0000-0002-3052-8020 \\ Sandra Espíndola LUNARDELLI' \\ (iD) ORCID iD 0000-0002-7836-6083 \\ Keila Cristina Raush PEREIRA ${ }^{2}$ \\ (iD) ORCID iD 0000-0002-1614-7854 \\ Simone Costa XAVIER ${ }^{2}$ \\ (i) ORCID iD 0000-0002-9204-6035 \\ Luiz Gustavo Teixeira MARTINS' \\ (ii) ORCID iD 0000-0003-0898-1440 \\ Eliane Azevedo TRAEBERT' \\ (iD) ORCID iD 0000-0001-9667-7216 \\ Jefferson TRAEBERT'
}

(ii) ORCID iD 0000-0002-7389-985X

\section{ABSTRACT}

\section{Objective}

To study the impact of dental trauma on the oral health-related quality of life among Brazilian students.

\section{Methods}

A cross-sectional study involving a representative sample of students of the public schools $(n=435)$ in a city in southern Brazil was carried out. Data on dental trauma were collected through oral examinations using the O'Brien's criteria (1993) restricted to fractures and avulsions. The Brazilian version of the Oral Impacts on Daily Performances (OIDP) was used in order to collect data on the impact of oral health-related quality of life. Bivariate and multivariate analysis were performed through Poisson log-linear regression with robust estimator with significance levels set at $p<0.05$. Prevalence ratios (PR) and confidence intervals (95\%) were estimated.

\section{Results}

The prevalence of dental trauma was $7.2 \%$, and it was associated with the following dimensions: performing daily activities [(PR = 3.52 $(95 \%$ Cl, 1.06-11.75)] $(p=0.040)$, and speaking [ $(P R=3.67(95 \% C l, 1.24-10.86)](p=0.019)$ after adjusting for sex, age, dental caries and malocclusion.

\section{Conclusion}

The prevalence of dental trauma found among this population was low, but significantly associated with oral health-related quality of life.

Indexing terms: Child health. Health evaluation. Quality of life. Surveys and questionnaires. Tooth injuries.

\section{RESUMO}

\section{Objetivo}

Estudar o impacto do trauma dental na qualidade de vida relacionada a saúde oral entre escolares brasileiros.

\section{Métodos}

Foi realizado estudo transversal envolvendo uma amostra representativa de escolares $(n=435)$ em uma cidade no sul do Brasil. Os dados sobre trauma dental foram coletados através de exames orais utilizando os critérios do O'Brien (1993), restritas a fraturas dentais e avulsões. A versão brasileira dos impactos no desempenho diário (OIDP) foi utilizado para recolher dados sobre o impacto na qualidade de vida relacionada à saúde bucal. O teste do qui-quadrado foi utilizado para a análise bivariada com níveis de significância de $p<0,05$. As razões de prevalência (RP) e intervalos de confiança (95\%) foram estimados utilizando regressão de Poisson log-linear com um estimador robusto.

\section{Resultados}

A prevalência de trauma dental foi de 7,2\%, e foi associado com as seguintes dimensões: realização de atividades cotidianas [(RP $=3,52$ (IC $95 \%, 1,06-11,75)](p=0,040)$, e falar [(PR = (IC 95\%, 1,24-10,86) 3,67] ( $p=0,019)$ após o ajuste para sexo, idade, cárie dentária e maloclusão.

\section{Conclusão}

A prevalência de traumatismo dentário encontrado entre esta população era baixa, mas significativamente associada à qualidade relacionada à saúde bucal de vida.

Termos de indexação: Saúde da criança. Avaliação em saúde. Qualidade de vida. Inquéritos e questionários. Traumatismos dentários.

\footnotetext{
${ }^{1}$ Universidade do Sul de Santa Catarina, Programa de Pós-graduação em Ciências da Saúde. Av. Pedra Branca, 25, Cidade Universitária, Pedra Branca, 88137-272, Palhoça, SC, Brasil. Correspondência para / Correspondence to: AN LUNARDELLI. E-mail: <abelardo.coe@terrra.com.br>.

${ }^{2}$ Universidade do Sul de Santa Catarina, Faculdade de Odontologia. Palhoça, SC, Brasil.

$\boldsymbol{\nabla} \mathbf{v}$

Como citar este artigo / How to cite this article

Lunardelli AN, Lunardelli SE, Pereira KCR, Xavier SC, Martins LGT, Traebert E, et al. Dental trauma and oral health-related quality of life in schoolchildren from public schools of a southern Brazilian city. RGO, Rev Gaúch Odontol. 2018;66(2):00-00. http://dx.doi.org/10.1590/1981863720180002000073300
} 


\section{INTRODUCTION}

Dental trauma, an oral health condition has aroused interest in the scientific community for different reasons. Together with dental caries, malocclusion and oral cancer, dental trauma has been regarded as a public health problem [1]. It has been observed that dental caries morbitiy indicators [2] decreased as well as recreational equipment and sports activities access increased. Potential fall risks and traumas, combined with the almost non-existing habit of wearing safety devices by children and adolescents [3], has highlighted the importance and interesnt in dental trauma studies. Nonetheless, the number of population-based epidemiological studies is still relatively small for Brazil, a country with continental and multicultural aspects. A study published in 2012 [4] pointed out that scientific studies involving Brazilian populations was restricted to 39 studies, of which 29 were population-based, followed by only two studies $[5,6]$, after this period.

Considering that dental trauma occurs most commonly in the anterior dental arch sextants, the negative impact on the children's life quality and their families may be high. The traumatic event itself which caused the dental trauma or the aesthetics compromised by a fractured or darkened tooth [4], together with the increased dental sensitivity, once the dentin has been exposed by the fissure [7] or another function commitment [4] may be responsible for these occurrences. Locker [8] has stated that oral condition can have both a positive as well a negative impact on people's living conditions.

A study carried out in England has highlighted the high cost of restorative dental trauma treatments, as well as school absenteeism, from post traumatic conditions [9]. In another research, an association between the occurrence of dental caries and untreated malocclusions along with children's unhappiness has been described. However, such association has not observed with the occurrence of dental trauma [10].

The dental trauma prevalence rates indicated by the studies have greatly varied [10-12]. Reports of negative impact associated with dental trauma, even in a small number, presented variations $[4,13,14]$. Few studies have analyzed the relationship between the prevalence magnitude and the impact generated, at the population level. Traebert et al. [4] have demonstrated a 79\% higher prevalence of impact reports associated with the occurrence of dental trauma in a population where the prevalence rate was $16.6 \%$.

Thus, this study is justified by the need for further studies on dental trauma impact on the quality of life routine of the affected children, even when the prevalence rate is low.

The aim of this study was to observe the possible association between the prevalence of dental trauma and the impact on daily performance in a population of schoolchildren in a city in southern Brazil.

\section{METHODS}

\section{Study design}

A cross-sectional study was carried out with schoolchildren enrolled in elementary public schools in the municipality of Tubarão, Santa Catarina state, Brazil, in 2012.

\section{Sampling}

The following parameters were used to calculate the sample size: a total of 6,554 students enrolled in the schools in the year the research was performed; confidence level of $95 \%$, relative error of $5 \%$. As the prevalence of impact of daily performance on the study population was unknown, 50\% was used, which generates the largest sample size. In order to compensate for any losses, to the calculated number of 363 students were added $20 \%$. Therefore, the minimum sample size was defined as 435 students, randomly selected, keeping the proportionality of students enrolled in small, medium-sized and large schools. The size of the schools was determined by the tertiary distribution in relation to the number of students enrolled. First, the schools were grouped according to size and then randomly assigned to those who would participate in the survey. After that, the selection of the students was randomly carried out, through a list provided by the each school secretary.

\section{Examiners' calibration and data collection}

Data collection included an interview with the students, followed by oral clinical examination in order to identify the dental trauma. The interviews were individually conducted with each student, at the school where he or she attended. The interview script covered questions about age and sex. To obtain data on the impact of oral health conditions on quality of life, the OIDP (Oral Impact on Daily Performance) indicator [13] validated in Brazil [14], was used. The indicator based on four questions related to eight daily activities as follows: eating, speaking, cleaning teeth, sleeping, maintaining emotional well-being, smiling, 
performing daily activities and maintaining social wellbeing. The oral examination was performed in classrooms by a team of four dentists and four notetakers who were wearing protective vests. Periodontal mirrors and periodontal probes were sterilized according to biosafety standards. In order to determine the presence of dental trauma, the examination included the eight anterior teeth, central and lateral incisors of both archs. In order to observe dental trauma O'Brien criteria [15] was used. Dental caries as well as its sequelae were observed in all teeth according to World Health Organization (WHO) criteria [16]. The occlusal condition was diagnosed based on the WHO criteria [16] for measuring the Dental Aesthetics Index (DAI). Both aimed to find out possible confounders. Prior to data collection, the team was calibrated by means of theoretical studies on the criteria, followed by the examinations of a sample of the schoolchildren regarding dental caries, malocclusion and dental trauma. Kappa values greater than 0.7 were obtained in inter and intraexaminer measurements.

A pilot study was conducted with $10 \%$ of the total sample, involving students who were not participating in the main study. The methodology showed to be adequate, with no need for adjustments. The data collected were inserted into a spreadsheet specially designed for this study where they were analyzed using SPSS 18.0 software. Bivariate and multivariate analyzes were performed using Poisson log-linear regression with robust estimator in order to determine the association between the dependent variable (OIDP> 0) and the independent variables (dental trauma, age, sex, dental caries and malocclusion) with a significance level of $p<0.05$. Raw and adjusted prevalence ratios (PR) and their respective confidence intervals (95\%) were also estimated.

This research project was submitted to and approved by the Research Ethics Committee of University of Southern Santa Catarina under number 11.142.4.02.III.

\section{RESULTS}

A total of 389 students were examined, generating a response rate of $89.4 \%$. Children aged 10 to 12 years old accounted for $67.4 \%$ of the sample, and female, $59.6 \%$ of the total. The prevalence rate of dental trauma was $7.2 \%$ (95\% Cl 4.7 to 9.7). The prevalence of dental caries was $55.5 \%(95 \% \mathrm{Cl} 50.6-60.4)$ and the mean DMFT was 0.99 (SD = 1.51). The prevalence of definite, severe or very severe malocclusion was $57.3 \%(95 \% \mathrm{CI} 52.3-62.1)$ (Tables 1 and 2).
Table 1. Distribution of students according to sex, age, dental trauma, caries and malocclusion. Tubarão (SC), 2012

\begin{tabular}{lll}
\hline Variables & $\mathbf{n}$ & \% \\
\hline Sex & 232 & 59.6 \\
Female & 157 & 40.4 \\
Male & & \\
Age (years) & 262 & 67.4 \\
From 10 to 12 & 127 & 32.6 \\
From 13 to 15 & & \\
Dental trauma & 28 & 7.2 \\
Yes & 361 & 92.8 \\
No & & \\
Caries & 216 & 55.5 \\
Yes & 173 & 44.5 \\
No & & \\
Malocclusion & 223 & 57.2 \\
Yes & 166 & 42.8 \\
No & & \\
\hline
\end{tabular}

Table 2. Description of the studied clinical conditions. Tubarão (SC), 2012.

\begin{tabular}{|c|c|c|}
\hline Dental trauma & $\mathbf{n}$ & $\%$ \\
\hline Upper right central incisor & 12 & 3.1 \\
\hline Upper left central incisor & 13 & 3.3 \\
\hline Upper right lateral incisor & 4 & 1.0 \\
\hline Upper left lateral incisor & 2 & 0.5 \\
\hline Lower right central incisor & 4 & 1.0 \\
\hline Lower left central incisor & 3 & 0.8 \\
\hline Lower right lateral incisor & 1 & 0.3 \\
\hline Lower left lateral incisor & 1 & 0.3 \\
\hline Dental aesthetic index & $\mathbf{n}$ & $\%$ \\
\hline Loss of incisors, canines or premolars & 10 & 2.6 \\
\hline Incisal crowding & 170 & 43.7 \\
\hline Incisal spacing & 87 & 22.4 \\
\hline Anterior maxillary misalignment & 111 & 28.7 \\
\hline Anterior mandibular misalignment & 148 & 38.1 \\
\hline Diastema & 55 & 14.1 \\
\hline Overjet $>3 \mathrm{~mm}$ & 120 & 30.9 \\
\hline Anterior crossbite & 3 & 0.8 \\
\hline Open bite & 10 & 2.6 \\
\hline Altered anteroposterior molar relationship & 129 & 33.2 \\
\hline Dental caries & Mean (SD)* & $\%$ \\
\hline DMFT & $0.99(1.51)$ & 100.0 \\
\hline D (Decayed) & $0.55(1.19)$ & 55.6 \\
\hline M (Missed due to caries) & $0.02(0.12)$ & 2.0 \\
\hline F (Filled) & $0.42(0.91)$ & 42.4 \\
\hline
\end{tabular}

Note: *SD = standard deviation. 
The average OIDP was 24.16 (SD = 2.71), with the median 25. The minimum and maximum OIDP values were 10 and 30, respectively. The distribution of schoolchildren who presentes an impact according to OIDP can be observed in Table 3. Proportionally, the activities that had the greatest impact on the sample studied were "eating" (28\%), "smiling" (26.5\%), "cleaning teeth" and "maintaining emotional-well being" (both with 19.5\%).

Table 3. Distribution and impact of dental trauma on daily performance according to Oral Impacts on Daily Performances (OIDP) domains. Tubarão (SC), 2012.

\begin{tabular}{|c|c|c|c|c|}
\hline \multirow{2}{*}{ Domain } & \multicolumn{4}{|c|}{ Impact on daily perfomance } \\
\hline & $\mathbf{n}$ & $\%$ & PR (Cl 95\%) & $\mathbf{p}$ \\
\hline Eating & 109 & 28.0 & $1.25(0.62-2.55)$ & 0.533 \\
\hline Cleaning teeth & 76 & 19.5 & $1.31(0.55-3.14)$ & 0.542 \\
\hline Sleeping & 34 & 8.7 & $2.41(0.95-6.13)$ & 0.065 \\
\hline Smiling & 103 & 26.5 & $1.36(0.66-2.77)$ & 0.402 \\
\hline Performing daily activities & 21 & 5.4 & $3.52(1.06-11.75)$ & 0.040 \\
\hline Maintaining social well-being & 76 & 19.5 & $0.56(0.07-4.29)$ & 0.576 \\
\hline
\end{tabular}

Note: PR $=$ Prevalence ratio. $\mathrm{Cl} 95 \%=95 \%$ Confidence interval. Reference group: children without dental trauma present. Adjusted for sex, age, dental caries and malocclusion.

The activities associated with dental trauma "speaking" ( $p=0.019)$ and "performing daily activities" $(p=0.040)$. Table 4 presents the raw and adjusted models of the two features associated with the prevalence of dental trauma. Schoolchildren presenting dental trauma showed a 3.67-fold higher prevalence of impact on "speaking" compared to those without dental trauma $[P R=3.67$ (95\% Cl 1.24-10.86)]. Regarding "performing daily activities" the magnitude of the prevalence ratio was 3.52 (95\% Cl 1.06-11.75). In both case, regardless of sex, age and presence of dental caries and malocclusion (Table 4).

Table 4. Crude and adjusted models for two OIDP domains associated to dental trauma. Tubarão (SC), 2012.

\begin{tabular}{|c|c|c|c|c|c|c|c|c|}
\hline \multirow{2}{*}{ Variables } & \multicolumn{4}{|c|}{ Speaking } & \multicolumn{4}{|c|}{ Performing daily activities } \\
\hline & $P_{c}(I C 95 \%)$ & $\mathbf{p}$ & $\mathrm{PR}_{\mathrm{a}}$ (IC 95\%) & $\mathbf{p}$ & $\mathrm{PR}_{c}(\mathrm{IC} 95 \%)$ & $\mathbf{p}$ & $\mathrm{PR}_{\mathrm{a}}$ (IC 95\%) & $\mathbf{p}$ \\
\hline Sex & & 0.901 & & 0.793 & & 0.023 & & 0.018 \\
\hline Male & 1.00 & & 1.00 & & 1.00 & & 1.00 & \\
\hline Female & $1.05(0.47 ; 2.37)$ & & $1.11(0.50 ; 2.45)$ & & $4.06(1.21 ; 13.55)$ & & $4.29(1.28 ; 14.39)$ & \\
\hline Age (years) & & 0.048 & & 0.055 & & 0.889 & & 0.934 \\
\hline From 10 to 12 & 1.00 & & 1.00 & & 1.00 & & 1.00 & \\
\hline From 13 to 15 & $3.09(1.01 ; 9.45)$ & & $2.34(0.98 ; 5.60)$ & & $1.06(0.44 ; 2.57)$ & & $1.04(0.42 ; 2.55)$ & \\
\hline Dental caries & & 0.046 & & 0.101 & & 0.043 & & 0.051 \\
\hline No & 1.00 & & 1.00 & & 1.00 & & 1.00 & \\
\hline Yes & $2.34(1.02 ; 5.39)$ & & $2.08(0.87 ; 4.98)$ & & $2.50(1.03 ; 6.05)$ & & $2.38(0.99 ; 5.69)$ & \\
\hline Malocclusion & & 0.229 & & 0.779 & & 0.664 & & 0.789 \\
\hline No & 1.00 & & 1.00 & & 1.00 & & 1.00 & \\
\hline Yes & $1.70(0.72 ; 4.04)$ & & $1.16(0.41 ; 3.27)$ & & $1.21(0.51 ; 2.85)$ & & $1.14(0.43 ; 3.00)$ & \\
\hline Dental trauma & & 0.006 & & 0.019 & & 0.033 & & 0.040 \\
\hline No & 1.00 & & 1.00 & & 1.00 & & 1.00 & \\
\hline Yes & $3.58(1.48 ; 8.92)$ & & $3.67(1.37 ; 9.82)$ & & $3.03(1.09 ; 8.40)$ & & $3.18(1.18 ; 8,58)$ & \\
\hline
\end{tabular}

Note: $\mathrm{PR}_{\mathrm{c}}=$ Crude prevalence ratio. $\mathrm{RP}_{\mathrm{a}}=$ Adjusted prevalence ratio. $\mathrm{Cl} 95 \%=95 \%$ Confidence interval. 


\section{DISCUSSION}

The good response rate obtained and the successful calibration process of the examiners have suggested excelente internal study validity. Some schoolchildren have not agreed to the oral exam, even with the free and informed consent signed by their parents, which has caused a less than $100 \%$ response rate. Positive indication for a good external validity was achiis related to the use of world and nationwide recommended criteria for the diagnosis of the studied clinical conditions. The found prevalence of dental trauma in the studied population may be considered low when compared to other studies conducted in Brazil $[4,10,13]$ and in other countries $[5,19,20]$. Such discrepancies could be partially attributed to possible differences in population age and the methodology used, particularly the studies conducted in both public or private schools, vaccination campaign populations and others, in addition to different diagnosis methodology.

Nonetheless, the low prevalence rate was associated with daily performance impact, at least in two diferent domais. The association of dental trauma with other variables has been the subject of research for more than two decades. Its relation to the impact on quality of life is more recent. However, a comparative analysis between the prevalence of dental trauma and the impact's magnitude needs further research. The non-association between dental trauma and dimensions related to aesthetics was unexpected and led to further investigation.

The sample showed the highest percentage of impacts reported by schoolchildren for "eating" (28\%), "smiling" (26.5\%) and "maintaining emotional wellbeing" (19.5\%) corroborated other studies [5,21-23]. Activities such as "smiling" and "social well-being", which are closely related to aesthetic standards, showed no statistical association with trauma, unlike previous results $[14,24,25]$.

"Speaking" and "performing daily activities" have shown remarkable high magnitudes and statistically significant association with dental trauma, even with a low prevalence in the studied population. Thus, the lowest percentages of impact activities with the lowest reported were those which presented statistical association. "Speaking" has a functional characteristic which can be pain-related present in fractures with pulp or dentine exposure [26] or with the dental anatomy after fracture, which may cause injuries in intraoral tissues.
As for the activities "eating", "speaking", "cleaning teeth", "smiling", "social well-being" and "maintaining emotional well-being" associations have not proved to be statistically significant with dental trauma. Probably, aesthetic and socialization activities were not of concern, in the sample studied, unlike the findings of Bendo et al. [19], where social interaction was the main concern in adolescents of the same age group. "Eating" and "cleaning teeth" were probably more related to posterior teeth which is less susceptible to dental trauma.

The use of an impact assessment indicator not specially designed for children which could in theory, underestimate the impact, was among the main limitations of this study. It is known that children have different perceptions on what can generate impact in their life. Activities such as "studying" and "relaxing" are not part of the index used in this study, impairing comparisons with more specific indices for youngsters. According to Barbosa $[26]^{26}$, children and adolescentes do not have the autonomy of an adult and their peculiar affection relationship with family and friends provide them with special quality of life perception.

Trauma and non-trauma dichotomization may also underestimate the impact on the quality of life of children and adolescents [25]. Severe trauma is usually less prevalent, however more distressing when analyzed separately.

Moreover, the cross-sectional design used in the present study is not adequate concerning whether dental trauma could be the cause of such impacts. Comparative longitudinal assessments of quality of life have been cited as important parameters for program development in the planning of public health policies $[22,24]$ suggesting that longitudinal study designs may be more adequate.

Additionally, sex, age, dental caries and malocclusion adjustments may disregard other confounding variables, therefore the results must be carefully interpretated. Moreover socioeconomic variable adjustment of schoolchildren and their families were not considered, even though they were from public schools. Some studies have related the low socioeconomic status, as well as low parents' schooling as predictors of dental trauma [2,27]. In contrast, access to sporting goods, homes with stairs and swimming pools, for example, may be related to a higher prevalence of dental trauma.

This study was carried out in a medium sized city in a southern Brazilian state involving a sample of children from elementary public schools. Therefore, the results 
could be applied for similar populations.

It has been concluded that the oral health-related quality of life associated with the occurrence of dental trauma may not be related to the magnitude of the prevalence rate. Even with low prevalence rate, there was found statistical association with children's and adolescents' quality of life negative impact, mainly related to functional activities, as observed in this study.

\section{Collaborators}

AN LUNARDELLI, analysis and interpretation of the data; writing the manuscript; final approval of the version to be published. SE LUNARDELLI, manuscript revision

\section{REFERENCES}

1. Petersen PE, Bourgeois D, Ogawa H, Estupinan-Day S, Ndiaye C. The global burden of oral disease and risks to oral health. Bull World Health Organ. 2005;83(9):661-9.

2. Lagerweij MD, van Loveren C. Decline caries trends: we are satified? Curr Oral Health Rep. 2015;2(4):212-7. doi: 10.1007/ s40496-015-0064-9

3. Sigurdsson A. Evidence-based review of prevention dental injuries. J Endod. 2013;39(3):S88-S93. doi: 10.1016/j. joen.2012.11.035

4. Traebert J, Lacerda JT, Page LAF et al. Impact of traumatic dental injuries on the quality of life of schoolchilden. Dent Traumatol. 2012;28:423-28. doi: 10.1111/j.1600-9657.2012.01114.x

5. Abanto J, Tsakos G, Paiva SM, Carvalho ST, Raggio DP, Bronecker M. Impact of dental caries and trauma on quality of life amoung 5-to 6-years-old children: perceptions of parents and children. Community Dent Oral Epidemiol. 2014;42(5):385-94. doi: 10.1111/cdoe.12099

6. Damé-Teixeira N, Alves LS, Ardenghi TM, Susin C, Maltz M Traumatic dental injury with treatment needs negatively affects the quality of life of Brazilian schoolchildren. Int J Paediatr Dent. 2013 Jul;23(4):266-73. doi: 10.1111/ipd.12002

7. Traebert J, Martins LGT, Traebert ESA, Bortoluzzi MC. Dental hot-cold sensitivity and Traumatic dental injuries. J Res Dent. 2014:2(2):111-18

8. Locker D. Deprivation and oral health: a rewiew. Community Dent Oral Epidemiol. 2000;28:161-69. doi: 10.1034/j.16000528.2000.280301.x

9. Ferratin S, Wong L, Kolokotsa K. The cost of treating children and adolescente with injuries to their permanente incisor at the dental hospital in United Kingdom. Dent Traumatol. 2004 Dec;20(6):327-33. doi: 10.1111/j.1600-9657.2004.00263.x

10. Tuchtenhagen S, Bresolin CR, Tomazoni F, da Rosa GN, Del Fabro $J P$, Mendes FM, et al. The influence of normative and subjective oral health status on schoolchildren's happiness. BMC Oral including important intellectual criticism of its content; final approval of the version to be published. KCR PEREIRA, study design; data collection; manuscript revision including important intellectual criticism of its content; final approval of the version to be published. SC XAVIER, study design; data collection; manuscript revision including important intellectual criticism of its content; final approval of the version to be published. LGT MARTINS, manuscript revision including important intellectual criticism of its content; final approval of the version to be published. EA TRAEBERT - manuscript revision including important intellectual criticism of its content; final approval of the version to be published. J TRAEBERT, analysis and interpretation of the data; writing the manuscript; final approval of the version to be published.

Health. 2015;15:15. doi: 10.1186/1472-6831-15-15.

11. Fakhunddin KS, Lawrence HP, Kenny DG, Locker D. Etiology and environment of dental injuries in 12-14-years-old Ontario schoolchildren. Dent Traumatol. 2008;24(3):305-8. doi: 10.1111/j.1600-9657.2007.00548.x

12. Traebert J, Marcon KB, Lacerda JT. Prevalência de traumatismo dentário e fatores associados em escolares no municípios de Palhoça. Cien Saude Colet. 2010;15:1849-55. doi: 10.1590/ S1413-81232010000700098

13. Cortes MI, Marcenes W, Scheiham A. Impact of traumatic injuries to the permanente teeth on the oral health-related quality of life in 12-14-years-old children. Community Dent Oral Epidemiol. 2002;30(3):193-8. doi: 10.1034/j.1600-0528.2002.300305.x

14. Ramos-Jorge $M L$, Bosco VL, Peres MA, Nunes $A C$. The impact of tratamento of dental trauma on quality of life of adolescents: a case-control study in Southern Brazil. Dent Traumatol. 2007;23:114-9.

15. Adulyanon S, Sheiham A. Oral impacts on daily performances, In: Slade GD, editor. Measuringoral health and quality of life. Chapel Hill, NC: University of North Carolina; 1997. p. 151-60.

16. Goes PSA. The prevalence and impact of dental pain in Brazilian schoolchildren and their families. London: University of London; 2001.

17. O'Brien M. Children's dental health in United Kingdon 1993. Office of population censuses and surveys. London: Her Majesty's Stationery Office; 1994.

18. World Health Organization. Oral health surveys: basic methods $4^{\text {th }}$ ed. Geneva: World Health Organization; 1997.

19. Bendo CB, Paiva, Torres CS, Oliveira AC, Grrousand D, Pordeus IA. Association betwen trated/untrated Traumatic dental injuries and impact on quality of life oj Brazilian scholchildren. Health Qual Life Outcomes. 2010;8:114.

20. Vieira-Andrade RG, Siqueira MBL, Gomes GB, D'Avila S, Pordeus IA, Paiva SM, et al. Impact of traumatic dental injury on the quality of life of Young children: a case-control study. Int Dent J. 2015;65(5):261-8. doi: 10.1111/idj.12182 
21. Paula JS, Leite $I C$, Almeida AB, Ambrosano GM, Pereira AC, Mialhe FL. The influence of oral health conditions, socioeconomic status and home environment factors on schoolchildren's selfperception of quality of life. Health Qual Life Outcomes. 2012 Jan 13;10:6. doi: 10.1186/1477-7525-10-6

22. Mathur MR, Watt RG, Millet CJ, Parmar P, Tsakos G. Deteminants of socioeconomic inequalities in Traumatic dental injuries amog urban indian adolescentes. PLoS ONE. 2015;10(10):e0140860 doi: 10.137/jounal.pone.0140860

23. Basavaraj P, Sunil MK, Nagarajappa R, Ashish S, Ramesh G. Correlation between oral health and Child-OIDP index in 12-and15-years-old children from Modinagar, India. Asia Pac J Public Health. 2014;26(4):390-400. doi: 10.1177/1010539513510553

24. Goes PS, Watt R, Hardy RG, Sheiham A. The prevalence and severity of dental pain in 14-15-year-old Brazilian schoolchildren. Community Dent Health. 2007;24(4):217-24.
25. Freire-Maia FB, Auad SM, Abreu MHN, Sardemberg F, Martins MT, Paiva SM, et al. Oral health-related quality of life and traumatic dental injuries in youg permanent incisors in Brazilian schoolchildren: a multilevel approach. PLosOne. 2015;10(8):e0135369. doi: 10.1371/journal.pone.0135369

26. Barbosa TS, Gavião MB. Oral health-related quality of life in children: part II. Effects of clinical oral health status. A systematic review. Int J Dent Hyg. 2008;6(2):100-7. doi: 10.1111/j.16015037.2008.00293.x

27. Locker D. Disparities in oral health-related quality of life in population of Canadian children. Community Dent Oral Epidemiol. 2007;35(5):348-56.

Received on: 27/10/2017

Final version resubmitted on: 16/11/2017

Approved on:23/3/2018 